\title{
Cocoa Fermentation from Agnéby-Tiassa: Biochemical Study of Microflora
}

\author{
Lialiane Maïmouna Kouamé, Gisèle Ahou Yah Koua*, Jacques Adom Niamké, \\ Bernadette Gblossi Goualié, Sébastien Lamine Niamké
}

Laboratory of Biotechnology, UFR Biosciences, Félix Houphouët-Boigny University, Abidjan, Côte d'Ivoire

Email address:

kouayahgisele@yahoo.fr (G. A. Y. Koua)

\section{To cite this article:}

Lialiane Maïmouna Kouamé, Gisèle Ahou Yah Koua, Jacques Adom Niamké, Bernadette Gblossi Goualié, Sébastien Lamine Niamké. Cocoa Fermentation from Agnéby-Tiassa: Biochemical Study of Microflora. American Journal of BioScience. Special Issue: Biotechnology. Vol. 3, No. 6, 2015, pp. 203-211. doi: 10.11648/j.ajbio.20150306.12

\begin{abstract}
Cocoa beans fermentation is an absolute requirement for the full development of chocolate flavor precursors. Here, we investigated the dynamic of microbial flora succession taking place in Agnéby-Tiassa cocoa fermentation. The results show that the first time of fermentation, the bacterial ecology quickly underwent changes characterized by the successional growth of lactic acid bacteria, yeasts, acetic acid bacteria and Bacillus. The dominance of Lactic acid bacteria observed at the onset of process was represented by a large proportion of homofermentative strains (98.88\%). Besides, all the LAB strains were able to metabolize glucose, fructose, sucrose and a proportion of $71.35 \%$ exhibit capacity to degrade citric acid. Yeasts population was characterized by a large diversity based on their carbon profile and their ability to produce pectinolytic enzymes (13.55\%) essential to degrade pectin of cocoa pulp. Furthermore, acetic acid bacteria were dominated by Acetobacter genus which represent $83.22 \%$ of AAB isolated. The later stages of fermentation were dominated by the presence of Bacillus strains which possess technological potentially as pectinolytic activity, capacity to metabolize citric acid and acidification capacity. Our results show that microflora isolated in this cocoa region producer behave differently and emphasize a microbial diversity existing in cocoa fermentation of Agnéby-Tiassa area.
\end{abstract}

Keywords: Cocoa Bean, Fermentation, Microflora, Agnéby-Tiassa, Côte d'Ivoire

\section{Introduction}

A microbial fermentation and drying process are required to initiate the formation of the precursors of cocoa flavor [1]. Cocoa beans fermentation involves a large number of different microorganisms, mainly yeasts, lactic acid bacteria (LAB), acetic acid bacteria (AAB) and Bacillus [2, 3], which is essential in determining the quality of cocoa beans aroma and future chocolate $[4,5,6]$. During the initial phases of the cocoa beans fermentation process, yeasts are favoured due to high sugar concentrations, low oxygen availability and low $\mathrm{pH}$. They consume citric acid producing ethanol, and present pectinolytic activity. The reduced oxygen availability, combined with increased temperature and $\mathrm{pH}$, favour the development of lactic acid bacteria (LAB), which consume citric acid and convert sugars to lactic acid. The increased aeration, due to pectin degradation, promotes the development of acetic acid bacteria (AAB), which ferment the ethanol, a highly exothermic process [2, 7, 8]. Concerning Bacillus species; many reports have indicated presence of various species which grow throughout of fermentation process $[3,9$, $10,11]$. This microbial activity generates a range of metabolites end-products such as alcohols and organic acids which diffuse into beans to cause their death. The change triggers an array of biochemical reactions and chemical changes within the beans, that are essential for the development of the characteristic cocoa flavour [12, 13, 14].

Many studies have reported the influence of cocoa pods origin and fermentation practices in the farm on the evolution of cocoa bean fermentation process [3, 7, 8, 15, 16]. They show that cocoa bean fermentation process differs from country to country, as it is often carried out according to typical local ways, differing in fermentation method, duration of the fermentation, and other operational practices on the farm, which may all impact the quality of the final products [3, $8,17]$. In Côte d'Ivoire, there are several cocoa-producing regions which give variable and non-reproducible quality of fermented cocoa beans. This variability has led to high 
economy loss over past years, evaluated at more than 200 billion francs CFA [18]. Understanding of microbial ecology of the fermentation process seems to be an efficient approach to control quality of cocoa fermented beans and reduce economic losses. In this context, Agnéby-Tiassa region one of the cocoa-producing regions of Côte d'Ivoire, with 26.180 tons of cocoa beans for campaign 2013-2014 [19], the microbial flora responsible of its fermentation is still unknown On the other hand, the few studies on Côte d'Ivoire microbiota reported in literature until now remain recent $[21,22,23,24$, $25,26]$. In this study, we investigated biochemical characteristics of microbial population involved in traditional cocoa bean fermentation of Agnéby-Tiassa and their impact on the quality of fermented beans.

\section{Materials and Methods}

\subsection{Fermentation Conditions and Sampling}

The ripe cocoa pods constituted of mixed genotypes (Forastero, Trinitario and Criollo cultivars) were harvested at a cocoa farm located in the region of Agnéby-Tiassa (geographic coordinates $6^{\circ} 00^{\prime}$ North $4^{\circ} 00^{\prime}$ West, Côte d'Ivoire). Cocoa pods were broken open manually with a knife, and beans were removed from pods and fermented traditionally by heap fermentation for six days. The fermenting mass about $150 \mathrm{~kg}$, set on banana leaves and covered with banana leaves. Each 12 hours the fermenting mass was turned. And then, $200 \mathrm{~g}$ of samples were collected randomly at the start of the fermentation $(0 \mathrm{~h})$ and after every $12 \mathrm{~h}$ until the end of fermentation. Samples collected were sealed in sterile bags (stomacher) transferred to the laboratory and stored in freezer at $-20^{\circ} \mathrm{C}$. Microbiological analyses were performed on the day of sample collection. The $\mathrm{pH}$ and temperature were also regularly recorded directly at $15 \mathrm{~cm}$ depth on the fermenting heap, with portable pHmeter and thermometer.

\subsection{Isolation and Enumeration of Microorganisms}

For culture-based quantification, $25 \mathrm{~g}$ of cocoa beans and adherent pulp was added to $225 \mathrm{ml}$ saline-peptone water $0.1 \%$ $(\mathrm{wt} / \mathrm{v})$ (Oxoid, Basingstoke, United Kingdom) in a sterile stomacher 400 (Seward, Worthington, United Kingdom), homogenised for $5 \mathrm{~min}$ and diluted serially. Samples $(0.1 \mathrm{ml})$ of the homogenate were plated on four different culture media following appropriate dilution for enumeration of the number of colony-forming units (CFU). Lactic acid bacteria (LAB) were enumerated by plate inoculation on MRS (Man Rogossa and Sharpe) agar supplemented with $0.1 \%(\mathrm{v} / \mathrm{v})$ nystatin to inhibit fungal growth. Plates were incubated at $30^{\circ} \mathrm{C}$ for $48-72 \mathrm{~h}$ under anaerobic conditions in a candle-jar. Concerning Acetic acid bacteria $(\mathrm{AAB})$, they were enumerated by surface inoculation on Duthathai agar as described by [19] method. The medium containing $0.5 \%$ D-glucose, $1 \%$ yeasts extract, $1 \%$ peptone, $2 \%$ glycerol, $1.5 \%$ potato and $4 \%$ ethanol (v/v), was supplemented with $0.0016 \%$ bromocresol green to monitor $\mathrm{pH}$ variation and nystatin $0.1 \%$ to inhibit fungal growth. The culture was incubated at $30^{\circ} \mathrm{C}$ to enable colony enumeration. Malt Yeast Peptone Glucose (MYPG) agar containing 3\% yeast extract, $3 \%$ malt extract, $5 \%$ peptone (Himedia), and $1 \%$ glucose, adjusted to $\mathrm{pH} 5.6$ supplemented with $100 \mathrm{mg} / \mathrm{L}$ chloramphenicol (Sigma, Paris, France) to inhibit bacterial growth, was used to enumerate yeasts population. The plates were incubated at $30^{\circ} \mathrm{C}$ for $72 \mathrm{~h}$. Bacteria of strain Bacillus were enumerated on Nutrient agar (NA) containing $0.1 \%$ nystatin to inhibit fungal growth. After the spreading, the plates were incubated at $30^{\circ} \mathrm{C}$ at $48 \mathrm{~h}$. Following incubation, the number of cell formed united (CFU) was recorded, followed by morphological characterization and counts of each colony type obtained, as described previously [27]. Phenotypic characterization of bacterial colonies originating from MRS, Duthathai agar, and NA plates was performed by conventional microbiological methods, including gram staining in conjunction with microscopic examination, catalase and oxidase activity and motility tests. The yeast colonies were physiologically characterized by determining their morphology. The strains isolated were stored at $-80{ }^{\circ} \mathrm{C}$ in Luria Bertani, MRS, MYPG and NA broth supplemented with $20 \%$ (v/v) glycerol in Eppendorf tubes, for further studies.

\subsection{Biochemical Characterization of Strains Isolated}

\subsubsection{Screening of Yeast Pectinolytic Strains}

Method described by [9] was used for the screening of yeast pectinolytic strains. Five wells of $0.5 \mathrm{~cm}$ in diameter and 2 to $3 \mathrm{~mm}$ in depth were made aseptically on plate agar containing a basal mineral medium $\left(0.28 \% \mathrm{NH}_{4} \mathrm{SO}_{4}, 0.6 \%\right.$ $\mathrm{K}_{2} \mathrm{HPO}_{4}, 0.01 \% \mathrm{MgSO}_{4}, 0.2 \% \mathrm{KH}_{2} \mathrm{PO}_{4}$, and $0.5 \%$ glucose) supplemented with $0.02 \%$ yeast extract, $1 \%$ pectin, and $1.7 \%$ agar adjusted $\mathrm{pH}$ to 5.6. Then pure yeast culture was suspended in saline tryptone to have an optical density of 1 at $600 \mathrm{~nm}$. The wells were subsequently loaded with $7 \mu 1$ of the suspension. All the wells of the same plate were inoculated with a single suspension. After $48 \mathrm{~h}$ incubation at $30^{\circ} \mathrm{C}$, the solid culture medium was flooded with a solution of iodine and potassium iodide ( $5 \mathrm{~g}$ potassium iodide, $1 \mathrm{~g}$ iodine and $330 \mathrm{ml}$ distilled water) to reveal the clear zones around the wells corresponding pectinolytic activity [28].

\subsubsection{Carbon Metabolism of Yeast Strains}

Following screening of pectinolytic activity of yeasts, a subset of 25 isolates was selected based pectinolytic activity for further analysis. The carbon metabolism study was carried out according to [29] method. A pre-culture was prepared by growing cells in malt extract broth $0.3 \%$ for $24 \mathrm{~h}$ at $30^{\circ} \mathrm{C}$. Then $10 \mu \mathrm{L}$ of the pre-culture $\left(\mathrm{OD}_{600}=0.5\right)$ were used to inoculate $10 \mathrm{~mL}$ of sterilized medium contained in 25 $\mathrm{mL}$ of tube. This medium, in which a Durham tube was inserted, was composed of $0.5 \%$ yeast extract and $2 \%$ of each carbohydrates tested (D-glucose, D-fructose, D-galactose, sucrose, maltose and lactose). Cultures were then incubated at $30^{\circ} \mathrm{C}$ for $48 \mathrm{~h}$ to 3 weeks. The presence of gas in Durham tubes indicates that the isolates ferment sugars with production of carbon dioxide $\left(\mathrm{CO}_{2}\right)$. 


\subsubsection{Carbon Metabolism of Lactic Acid Bacterial Strains}

Carbon metabolism of LAB isolates were carried out to evaluate their ability to produce acid by catabolizing glucose, fructose and sucrose. The study of sugars metabolism was performed in a modified MRS medium containing the appropriate carbohydrate at $2 \%$ as sole carbon source, $1.7 \%$ agar and supplemented with $0.005 \%$ of bromocresol purple. Each strain was cultivated by central sting in the medium and then incubated at $30{ }^{\circ} \mathrm{C}$ for $72 \mathrm{~h}$ in anaerobic conditions. A negative control was prepared in the same conditions and not inoculated with the microbial culture. The capacity of strains to metabolize the carbon source is assessed by the presence of colony in the tube and the change of medium colour due to $\mathrm{pH}$ lowering, comparatively to the negative control.

\subsubsection{Fermentative Type of LAB Strains}

Fermentative type of bacterial strains was evaluated by [30] method with slight modification. Each strain was cultivated and incubated as described above, in the same MRS medium. The carbohydrates tested were glucose, fructose and sucrose. The fermentative type was determined by ability of strains to produce gas from carbon source. Heterofermentative LAB type was identified by the presence of gas at the bottom of the tube with yellow zone.

\subsubsection{Citrate Metabolism of $L A B$}

The capacity of LAB strains to metabolize citrate was performed according to [31] method. KMK agar containing 1\% skimmed milk powder, $0.5 \%$ casein peptone, $0.5 \%$ glucose and $1.5 \%$ agar added with $1 \mathrm{~mL}$ of two solutions $\mathrm{A}$ and $\mathrm{B}$ was used. The solution (A) of potassium ferricyanide $\left(\mathrm{K}_{3} \mathrm{FeCN}\right)$ was prepared at $10 \%$ in water distilled. The solution (B) containing $1 \mathrm{~g}$ iron citrate and $1 \mathrm{~g}$ sodium citrate was prepared in $40 \mathrm{~mL}$ of distilled water. The medium was inoculated by spot with pure $24 \mathrm{~h}$ pre-culture of $\mathrm{LAB}$ strains and then incubated at $30^{\circ} \mathrm{C}$ for $48 \mathrm{~h}$. After incubation, the colonies which appear blue on the medium are the microorganisms which are able to metabolize citrate "citrate (+)" and white colonies characterized by microorganisms which are not able to metabolize citrate "citrate $(-)$ ".

\subsubsection{Acidification Capacity of $A A B$}

Acidification capacity of AAB strains was performed using an adapted [32] method with slight modification. Hestrin-Schramm (HS) agar containing 0.05\% D-glucose, $0.5 \%$ yeasts extract, $0.3 \%$ casein peptone, $2 \%$ glycerol, $1.5 \%$ calcium carbonate, $1.5 \%$ ethanol $(\mathrm{v} / \mathrm{v})$ and $1.5 \%$ agar, supplemented with $0.0016 \%$ bromocresol green, adjusted at pH 6.8, was used. Then HS agar was spot inoculated with pure $24 \mathrm{~h}$ pre-culture of AAB strains and incubated at $30^{\circ} \mathrm{C}$ for 10 days. Acid production was monitored by formation of yellow halo around the spot and acidification capacity of strains was evaluated each day by measuring of halo diameter.

\subsubsection{Distinction of AAB by over Oxidation Test}

This test evaluated the ability of the isolates of acetic bacteria to carry out over oxidation of lactic and acetic acids by the HS medium. The modified HS medium containing $0.05 \%$ glucose and $1 \%$ acetic acid or lactic acid as a carbon source was used. Addition of acetic acid or lactic acid to the HS broth provokes the change of the green medium color into yellow. Five milliliters of medium contained in a $20 \mathrm{ml}$ flask were inoculated with the bacterial pre-culture and incubated at $30^{\circ} \mathrm{C}$ for $48 \mathrm{~h}$. Over oxidation of acetic acid into $\mathrm{CO}_{2}$ and $\mathrm{H}_{2} \mathrm{O}$ was assessed by the change of medium color back to green, due to $\mathrm{pH}$ rising.

\subsubsection{Screening of Bacillus Strains for Pectinolytic Activity}

The method [9] described previously was used to evaluate the capacity of Bacillus strains to degrade pectin as sole carbon source.

\subsubsection{Citrate Metabolism of Bacillus Strains}

The capacity of Bacillus strains to metabolize citrate was carried out according to [31] method described previously using KMK agar added with solutions $\mathrm{A}$ and $\mathrm{B}$ of potassium ferricyanide. After incubation at $30^{\circ} \mathrm{C}$ for $48 \mathrm{~h}$, the colonies which appear blue on the medium are able to metabolize citrate and white colonies characterized microorganisms which are not able to metabolize citrate.

\subsubsection{Acidification Capacity of Bacillus Strains}

Bacillus strains were evaluated to their acidification capacity using an adapted method [32] described previously. The inoculation was carried out by central sting of HS medium flowed on tube with the pure $24 \mathrm{~h}$ pre-culture of Bacillus and incubated at $30^{\circ} \mathrm{C}$ for $48 \mathrm{~h}$. A negative control was prepared in the same conditions excepted that it was not inoculated with the microbial culture. Acid production was monitored by formation of yellow area in the tube with or not production of gas. Acidification capacity of Bacillus was determined by evaluating in a visual based.

\section{Results and Discussion}

The study reveals that the temperature inside the Agnéby-Tiassa fermenting cocoa mass ranged from an initial $28^{\circ} \mathrm{C}$ to a maximum $46^{\circ} \mathrm{C}$ obtained after $36 \mathrm{~h}$ of fermentation (Figure 1). Then the temperature decreased progressively, dropping at $30^{\circ} \mathrm{C}$ at the end of process. The initial $\mathrm{pH}$ at the start of the fermentation was 4.46 and decrease slightly to 4.05 at 24 hours (Figure 1). Then the value increased progressively to 5.86 at $60 \mathrm{~h}$ and rose sharply to reach its maximum value 7.12 at the end of the fermentation process. The similar pattern was reported in others cocoa fermentation in many countries $[1,6,33,34,35]$. According to a report [22], the increase of both parameters seems to be an inherent property of cocoa fermentation worldwide. However, the acid $\mathrm{pH}$ observed at the beginning of fermentation is known to depend primarily on the presence of citric acid in cocoa beans mucilage [36] and its increase was associated to citric acid consumption [2, 30]. Moreover, alkaline $\mathrm{pH}$ reached at the end of process was also been reported by some authors [9], [35] and [37] in Ivorian cocoa fermentation. This situation seems to be a particularly of Côte d'Ivoire cocoa fermentation, since alkaline $\mathrm{pH}$ has not 
been yet reported in other country. According to a report [2], increasing of temperature observed during fermentation process was associated to intense metabolic activity of microorganisms that occurred during this process, reaching sometimes about $50^{\circ} \mathrm{C}$ at the end of the process. Overall, temperature and $\mathrm{pH}$ changes showed in cocoa fermentation provided an ecosystem that selected for the successional growth of various species of yeasts, lactic acid bacteria, acetic acid bacteria and Bacillus.

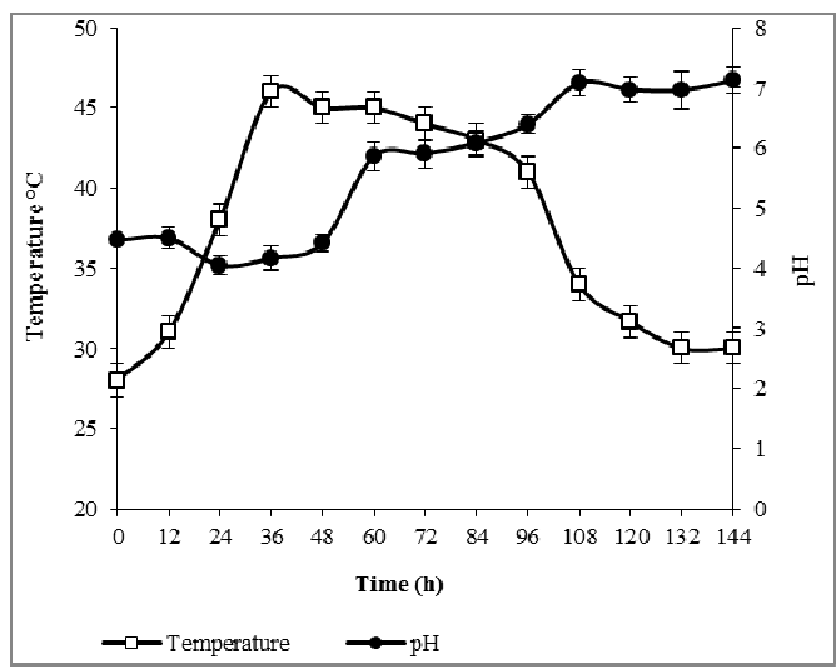

Figure 1. Evolution of temperature and $\mathrm{pH}$ during cocoa fermentation. Error bars indicates standard deviation between three replicates.

The dynamic of microorganism population obtained from numeration during cocoa fermentation process are shown on Fig 2. The results revealed that at the beginning of fermentation, yeasts, lactic acid bacteria and Bacillus were present with different level of bacterial load. Among them, LAB were the most important bacterial load to 6.18 log UFC $\mathrm{g}^{-1}$ of beans compared with yeasts and Bacillus load to 5.90 and $5.91 \log$ CFU g ${ }^{-1}$ of beans, respectively. The acetic acid bacteria populations were undetectable at the beginning of process.

During the fermentation, the LAB population increased sharply to reach a peak of $7.27 \log \mathrm{CFU} \mathrm{g} \mathrm{g}^{-1}$ of beans at $12 \mathrm{~h}$ while yeasts population obtained maximum load $7.46 \mathrm{log}$ $\mathrm{CFU} \mathrm{g}{ }^{-1}$ of beans at $36 \mathrm{~h}$ of fermentation. Acetic acid bacteria population started to develop after $12 \mathrm{~h}$ with bacterial load $5.72 \log \mathrm{CFU} \mathrm{g} \mathrm{g}^{-1}$ of beans and the bacterial load increased rapidly to reach a peak of $7.72 \log$ CFU g ${ }^{-1}$ of beans at $60 \mathrm{~h}$. Concerning Bacillus populations, the number remained high throughout the fermentation and reached the most important peak of $8.08 \log \mathrm{CFU} \mathrm{g} \mathrm{g}^{-1}$ of beans at the end of fermentation process. However, the results show that generally high decrease of bacterial load of different microorganisms was observed after the peak and became undetectable at the end of the process. The presence of flora bacterial at the start of cocoa fermentation was similar to that observed in many countries [ 3 , 38]. According to some authors [2, 39, 40], microorganisms which colonized cocoa fermenting mass come from the cocoa pod surface mainly, hands of workers, knives, unwashed baskets used for transport of seeds, and dried mucilage left on the walls of boxes from previous fermentations. It indicates that the fermentation of cocoa is a spontaneous microbiological process. In the initial phases of the fermentation, growth of yeasts and LAB are favoured as regard increase of load bacterial level to the first time of process at 12 and $36 \mathrm{~h}$ of fermentation, respectively. Thereafter, their population declined to nondetectable levels until fermentation was terminated. These findings agree with previous studies conducted in other countries [38, 41, 42]. It has been admitted that the initial acidity of the pulp ( $\mathrm{pH} 3.6)$ together with the high sugar content and limited oxygen availability in the pulp, favour colonization by yeasts $[2,3]$. While the amended conditions favour the development of lactic acid bacterial. They metabolism conduct mucilage breakdown which consequence was modification of aeration conditions and produces fermentable carbohydrate substrates [34]. The changes of fermentative mass conditions associate to rise of temperature above $37^{\circ} \mathrm{C}$ are great to acetic acid bacteria development which became the dominant organisms (bacterial load) at $60 \mathrm{~h}$ of process. This stage of microbial succession is reflected by a decline of the concentration of ethanol and increase of acetic acid. The exothermic reactions of acetic acid bacteria raise the temperature of the fermenting mass even further up to $50^{\circ} \mathrm{C}$ or more. It seems that the decrease in the number of acetic-acid bacteria from three days onwards is probably due to their inhibition by the high temperature in the cocoa mass which occurred $[2,11]$. As regard the Bacillus population, the numbers still persisted throughout the process and were the dominant microflora after $84 \mathrm{~h}$ until the end of process. Their simultaneous growth with that of yeasts, $\mathrm{LAB}$ and AAB, as too observed in Indonesia [3] and Ghana fermentations [8] may indicate that these strains had an exceptional ability to proliferate under very extreme conditions and to use a big diversity of carbon sources [43]. Indeed, towards the end of the fermentation, the major sources of carbon are organic acids such as acetic acid and lactic acid, and mannitol. Moreover, the report [44], indicated that many Bacillus species are able to use those compounds as a source of energy. This can explain probably the growth of Bacillus species during the later stages of process.

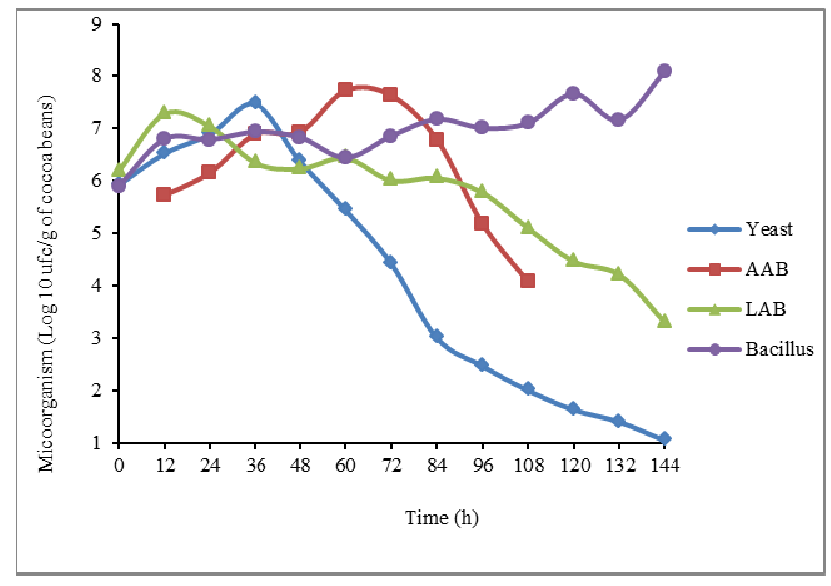

Figure 2. Microorganism growths dynamic during cocoa fermentation. 
The variation of physical and chemical parameters associated to the microbial succession dynamic which take place and the technological role of each microorganism in cocoa fermentation shaping the quality of the commercial cocoa beans.

Biochemical identification of yeast strains isolated from Agnéby-Tiassa cocoa fermentation, revealed that of them 230 isolates. A relatively low proportion of $13.55 \%$ (32 strains) was able to degrade pectin as sole carbon source. Based on halo diameter, pectinolytic strains were classified into three groups: the first group concerned high strains producing 2-3 $\mathrm{cm}$ of halo diameter, second group comprised strains yielding $1.5-2 \mathrm{~cm}$ halo diameter corresponding to a middle pectinolytic activity and the last group of strains presented low pectinolytic activity with halo diameter ranging in $1-1.4 \mathrm{~cm}$ (Figure 3 ). Activity of pectinolytic yeast strains in cocoa fermentation was also reported by some authors [17]. This technological property of yeasts strains is very important for cocoa fermentation process [2, 45]. Indeed, according to [45] pectinolytic activity of yeasts contributes to change aeration at the beginning of the cocoa fermentation and seemed to be more relevant to improve bean quality.
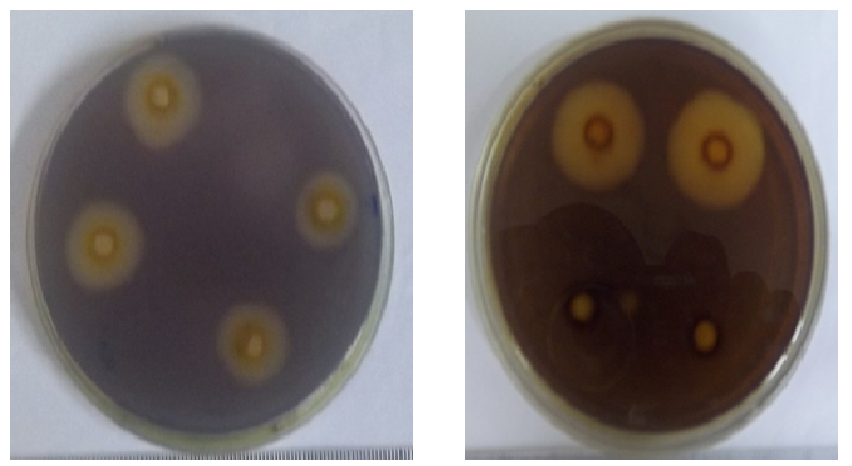

Figure 3. Screening of yeast strains with different levels of pectinolytic activity.

Hence the best pectinolytic yeasts isolated based on halo diameter were further studied for their carbon metabolism. Table 1 shows the carbohydrates profile of pectinolytic yeast strains. Ten profiles were obtained: the profile 2 recording the most important number of pectinolytic yeast strains (48\%) which is characterized by ability to ferment glucose and fructose, while the profile 1 included pectinolytic yeast (20\%) which is able to metabolize glucose, fructose and sucrose. The isolate T0Ys6 of profile 5 was able to metabolize all the tested sugars. The number of profile obtained indicating probably a wide diversity of yeast species isolated of Agnéby-Tiassa fermentation. Besides, nearly of the half of strains (48\%) were able to metabolize glucose and fructose while $20 \%$ ferment glucose, fructose and sucrose which are the main carbohydrates contained in the cocoa pulp [46]. The high diversity of pectinolytic yeast presents in this area may constitutes a potential influence on the quality of fermented dry cocoa beans and chocolates produced thereof.

One hundred seventy-eight (178) LAB strains characterized as Gram positive, oxidase negative, catalase negative and cocci or rods shaped were isolated during the cocoa fermentation. Thirty-seven (37) isolates were lactococci $(20.79 \%)$ and 141 were lactobacilli $(79.21 \%)$. The similar observation has been reported in Ghanaian and Nigerian cocoa fermentation [40, 41]. Moreover, our results showed that homofermentative strains $(98.88 \%)$ are widely dominant among LAB isolated from Agnéby-Tiassa cocoa fermentation (Table 2).

Table 1. Fermentative profile of pectinolytic yeast strains.

\begin{tabular}{llllllll}
\hline \multirow{2}{*}{ Profiles } & \multicolumn{1}{c}{ Glu } & Fru & Suc & Mal & Lac & Gal & \\
\cline { 2 - 6 } & + & + & + & - & - & - & 5 \\
Profile 1 & + & + & - & - & - & - & 12 \\
Profile 2 & + & + & - & - & - & + & 1 \\
Profile 3 & + & + & + & + & + & + & 1 \\
Profile 4 & + & + & + & + & - & + & 1 \\
Profile 5 & + & + & + & - & + & + & 1 \\
Profile 6 & + & + & + & - & - & + & 1 \\
Profile 7 & + & + & + & + & - & - & 1 \\
Profile 8 & + & + & - & + & - & - & 1 \\
Profile 9 & + & - & - & - & - & - & 1 \\
Profile 10 & + &
\end{tabular}

Glu: glucose; Fru: fructose; Suc: sucrose; Mal: maltose ; Lac : lactose ; Gal : galactose

$+:$ positive, -: negative

These results are not consistent with those found in Ghanaian fermentation [8]; Indonesian fermentation [3] and Dominican Republic fermentation [34] which reported that heterofermentative $\mathrm{LAB}$ constitute the major group occurring during cocoa beans fermentations. This difference of LAB community observed in fermentation process of this area could explain the difference of quality existing between Ivorian commercial cocoa beans and others cocoa region producing. On the other hand, it has known that the acidity produced by lactic bacteria is not desirable due to the negative impact on the cocoa beans [2]. However, more recent reports [47] are demonstrated that high level of lactic acid in cocoa beans fermenting mass may allow enhanced growth of Acetobacter genus which is able to metabolize lactic acid. Consequently, predominance of homofermentative forms in Agnéby-Tiassa cocoa fermentation may constitute an alternative asset considering the important role of $\mathrm{AAB}$ in fermentative process and on the quality of end products. Besides, the LAB strains isolated were analysed and screened for their ability to produce acid by catabolizing glucose, fructose, sucrose and citrate. The results revealed that all of the strains are able to metabolize glucose, fructose, sucrose and a wide proportion of strains $(71.35 \%)$ fermented citrate (Table 2). These results are consistent with the observation according to some lactic acid bacteria species may metabolize pulp citric acid $[2,13]$. This confirmed the prominent growth of lactic acid bacteria during the first 2 days of fermentation. Citrate metabolism constitutes an important and particular property. Indeed, the citric acid is responsible for the initial $\mathrm{pH}$ of cocoa pulp before fermentation processing [3; 13, 48, 49] and it degradation in the first stage of fermentation allows the raise of the $\mathrm{pH}$ favourable for the development of many bacterial groups which may contribute to impact positively 
cocoa bean quality $[2,50]$.

Table 2. Distribution of LAB strains according to the carbon metabolism.

\begin{tabular}{llllll}
\hline \multirow{2}{*}{ Profiles } & \multirow{2}{*}{$\begin{array}{l}\text { Tested } \\
\text { strains }\end{array}$} & \multicolumn{4}{l}{$\begin{array}{l}\text { Number of LAB } \\
\text { metabolizing the sugar }\end{array}$} \\
\cline { 3 - 6 } & & Glu & Fru & Suc & Citr \\
\hline lactobacilli & 141 & 141 & 141 & 141 & \multirow{2}{*}{$127(71.35 \%)$} \\
Lactococci & 37 & 37 & 37 & 37 & \\
\hline
\end{tabular}

Glu: glucose; Fru: fructose; Suc: sucrose; Citr: citrate.

With respect to $\mathrm{AAB}$, the isolates Gram negative, oxidase negative, catalase positive, straight or slightly curved were selected. Among the 155 strains, $26(16.77 \%)$ were Gluconobacter and 129 (83.22\%) were Acetobacter genus. The genera Acetobacter were able to oxidize acetic acid and lactic acid to $\mathrm{CO}_{2}$ and $\mathrm{H}_{2} \mathrm{O}$ indicated by turning of medium from yellow to green (Figure 4). This observation was not the same for Gluconobacter genera. The same observation has been regularly recorded in cocoa beans fermentation $[8,14]$. According to these authors, from the 10 existing genera of $\mathrm{AAB}$, only the Acetobacter and Gluconobacter genera were reported to colonize cocoa beans fermenting mass [51], with the Acetobacter genus dominant [51, 52]. Gluconobacter genus is known to oxidize ethanol to acetic acid and species from the genus Acetobacter have the additional capacity to oxidize acetic acid to carbon dioxide and water [53]. It known that production of acetic acid during cocoa fermentation is desirable for development of precursors chocolate aroma $[54,55]$. At date, the possible impact of the balance between both types of $\mathrm{AAB}$, on the quality of bean is not established.

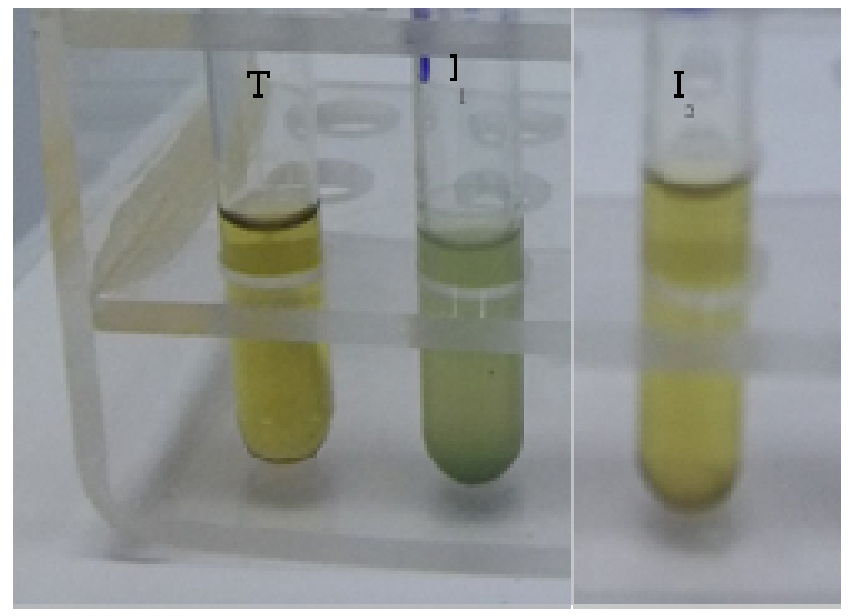

T: control test, $\mathrm{I}_{1}$ : positive test corresponding to Acetobacter genus, $\mathrm{I}_{2}$ : negative test corresponding to Gluconobacter genus

Figure 4. Over oxidation of $A A B$ strains.

All the $\mathrm{AAB}$ isolates were screened for their capacity to acidify solid medium as evidenced by yellow halo round the colonies. The halo diameters ranged from 0.7 and $3.1 \mathrm{~cm}$. All the $\mathrm{AAB}$ strains showed naturally acidification capacity but with different levels. On based the halo diameter produced three strains groups were identified, 69 strains $\mathrm{AAB}$ produced high acidity with halo diameter to $1.7-3.1 \mathrm{~cm}$. With a halo diameter ranged from 1.1-1.7 cm, 73 strains were considered to produce middle acidity and 13 isolates showed low acidity capacity. This property is agreed with the classic description of these bacteria in the literature [56]. As described previously, acidification during cocoa fermentation caused by acetic acid was positive effect and contributes for development of characteristic flavour of chocolate [57].

Three hundred and three (303) isolates of Bacillus were isolated from cocoa fermentation and screened at the first time for pectinolytic activity. A number of 101 (32.16\%) were positive for pectin degradation based present of clear halo round colonies. Among them, 5 presented the most important pectinolytic activity with halo diameter ranged from 2.7-3.4 cm, 46 produced middle activity with halo diameter comprised to $2-2.6 \mathrm{~cm}$ and 50 strains showed low pectinolytic activity. Our results show that the proportion of pectinolytic Bacillus strains is less than these recorded by some others authors $[9,28]$ which reported $61 \%$ and $91.83 \%$ of bacilli, respectively. But it confirms the finding of the author [9] indicating that the degradation of the pulp during cocoa fermentation might not be only due to pectinolytic yeasts. Moreover, several authors [16, 42] reported a dramatic decline of yeasts population after $24 \mathrm{~h}$ of fermentation emphasizing the important role that Bacillus pectinolytic enzymes producer may play in the remaining time of cocoa fermentation.

Screening of Bacillus strains for citrate metabolism as sole carbon source and acidification capacity in solid medium revealed that 149 strains $(47.60 \%)$ were able to metabolize citrate and 174 strains $(60 \%)$ were acidified solid medium as evidenced by the turning from green to yellow colour. This finding demonstrated the most important role of Bacillus strains in cocoa fermentation. It indicates that Bacillus strains involved in Agnéby-Tiassa cocoa fermentation have interesting potentialities and could contribute to enhance fermented and dried cocoa bean quality.

\section{Conclusion}

The study had revealed that Agnéby-Tiassa cocoa fermentation is characterized by LAB strains presenting high homofermentative metabolism. These bacteria were able to metabolize citrate as carbon source, a valuable property for cocoa fermentation. The results indicated that Bacillus strains present in this region were also characterized by ability to metabolize citrate but an addition they were able to produce pectinolytic enzymes and to acidify culture medium. Concerning yeast strains, they are composed mainly of pectinolytic strains in low proportion $(13.55 \%)$ which possessed a large diversity based on their carbon metabolism profile. Furthermore, AAB population was highly dominated by the type Acetobacter rather than Gluconobacter. All together, these results show that microflora isolated in this cocoa-producing region behave differently and emphasize a microbial diversity existing in cocoa fermentation of Agnéby-Tiassa. 


\section{References}

[1] Lopez, A. S. and Dimick, P. S. (1995). Cocoa fermentation. In: Weinheim V. C. H., (Ed) by Reed, G. and Nagodawithana, T. W., Enzymes, biomass, food and feed, 2nd Edition, Germany, pp.561-577.

[2] Schwan, R. F. and Wheals, A. E. (2004). The microbiology of cocoa fermentation and its role in chocolate quality. Cri. Rev. Food Sci. Nutr. 44:204-221.

[3] Ardhana, M. M. and Fleet, G. H. (2003). The microbial ecology of cocoa bean fermentations in Indonesia. Int. J. Food Microbiol. 86:87-99.

[4] Thompson, S. S., Miller, K. B. and Lopez, A. S. (2007). Cocoa and coffee. Food Microbiology. In: Doyle, M. P. and. Beuchat, L. R. (eds), Fundamentals and Frontiers. 3rd Edition, ASM Press, Washington, D. C, pp. 837-850.

[5] De Vuyst, L., Lefeber, T., Papalexandratou, Z. and Camu, N. (2010). The functional role of lactic acid bacteria in cocoa bean fermentation. In: Mozzi F., Raya R. R. and Vignolo G. M. (Eds), Biotechnology of Lactic Acid Bacteria: Novel Applications, Wiley-Blackwell, Ames, pp. 301-326.

[6] Papalexandratou, Z., Vranckena, G., De Bruyne, K., Vandamme, P. and De Vuyst, L (2011). Spontaneous organic cocoa bean box fermentations in Brazil are characterized by a restricted species diversity of lactic acid bacteria and acetic acid bacteria. Food Microbiol. 28:1326-1338.

[7] Jespersen, L., Nielsen, D. S., Honholt, S. and Jakobsen. M. (2005). Occurrence and diversity of yeasts involved in fermentation of West African beans. FEMS Yeast Res. 5:441-453.

[8] Nielsen, D. S., Teniola, O. D., Ban-Koffi, L., Owusu, M., Andersson, T. S. and Holzapfel, W. H. (2007). The microbiology of Ghanaian cocoa fermentations analysed using culture-dependent and culture independent methods. Int. J. Food Microbiol. 114:168-186.

[9] Ouattara, H. G., Koffi. B. L., Karou,. G. T., Sangare, A., Niamke, S. L. and Diopoh, J. K. (2008). Implication of Bacillus sp. in the production of pectinolytic enzymes during cocoa fermentation. World J. Microbiol. Biotech. 24:1753-1760.

[10] Garcia-Armisen, T., Papalexandratou, Z., Hendryckx, H., Camu, N., Vrancken, G., De Vuyst, L. and Cornelis. P. (2010). Diversity of the total bacterial community associated with Ghanaian and Brazilian cocoa bean fermentation samples as revealed by a 16SrRNA gene clone library. Appl. Microbiol. Biotechnol. 87: 2281-2292.

[11] Lima, L. J. R., Almeida, M. H., Nout, M. J. R. and Zwietering, M. H. (2011). Theobroma cacao L., "the food of the gods": quality determinants of commercial cocoa beans, with particular reference to the impact of the fermentation. Crit. Rev. Food Sci. 52:731-716.

[12] Hashim P, Selamat J, Kharidah S and Ali A. (1998). Changes in free amino acid, peptide- $\mathrm{N}$, sugar and pyrazine concentration during cocoa fermentation. J. Sci. Food Agr. 78:535-542

[13] Thompson, S. S., Miller, K. B. and Lopez, A. S. (2001). Cocoa and coffee. In: Doyle M. P., Beuchat L. R. and Montville T. J.
(Ed), Food microbiology: fundamentals and frontiers, 2nd Edition, ASM Press, Washington, DC, pp. 721-733.

[14] Pereira, D. G. V., Pedrozo-Miguel, M. G., Ramos, C. L. and Schwan, R. F. (2012). Microbiological and physicochemical characterization of small scale cocoa fermentations and screening of yeast and bacterial strains to develop a defined starter culture. Appl. Env. Microbiol. 78: 5395-5405.

[15] Nielsen, P. S. (2006). Determination of the degree of cocoa fermentation using spectroscopy and multivariate data analysis. Master Thesis, Department of Food Science. The Royal Veterinary and Agricultural University, Denmark, $111 \mathrm{p}$.

[16] Wood, G. A. R. and Lass, R. A. (2001). Cocoa, 4th eds. Longman. Group Limited, London.

[17] Schwan, R. F. (1998). Cocoa fermentations conducted with a defined microbial cocktail inoculum. Appl. Env. Microbiol. 64: 1477-1483.

[18] Camu, N., De Winter, T., Verbrugghe, K., Cleenwerck, I., Vandamme, P., Takrama, J. S., Vancanneyt, M. and De Vuyst, L. (2007). Dynamics and biodiversity of populations of lactic acid bacteria and acetic acid bacteria involved in spontaneous heap fermentation of cocoa beans in Ghana. Appl. Env. Microbiol. 73:1809-1824.

[19] Anonymous 2015. http://www.conseilcafecacao.ci/docs/PROGRAMME_2QC_2 014-2023 pdf.

[20] Anonymous 2015.2 Fratmat. Info. http://framat.info/ecomonie/item/18251-caf\%CA9-cacao-le-co nseil-cf\%C3\%A9-cacao-va-traiter-66000 ha.

[21] Ouattara, H. G, Reverchon, S., Niamke, S. L. and Nasser, W. (2011). Molecular identification and pectate lyase production by Bacillus strains involved in cocoa fermentation. Food Microbiol. 28: 1-8.

[22] Guéhi, S. T., Dabone. S., Ban-Koffi, L., Kra, D. K. and Zahouli, G. I. (2010). Effect of turning beans and fermentation method on the acidity and physical quality of raw cocoa beans. Adv. J. Food Sci. Technol. 2:163-171.

[23] Samagaci, L., Ouattara, H. G., Goualié, B. G. and. Niamke, S. L. (2014). Growth capacity of yeasts potential starter strains under cocoa fermentation stress conditions in Ivory Coast. Emir. J. Food Agric. 20: 861-870.

[24] Yao, W., Ouattara, H. G., Goualie, B., Soumahoro, S. and Niamke, S. (2014). Analysis of some functional properties of acetic acid bacteria involved in Ivorian cocoa fermentation. J. Appl. Biosci. 75:6282-6290.

[25] Ouattara, D. H., Ouattara H. G., Goualié B. G., Kouamé L. M. and Niamke, S. L. (2014). Biochemical and functional properties of lactic acid bacteria isolated from Ivorian cocoa fermenting beans. J. Appl. Bios. 77:6489- 6499.

[26] Samagaci, L., Ouattara, H. G., B. Goualié G. and. Niamke, S. L. (2015). Polyphasic Analysis of Pectinolytic and Stress-Resistant Yeast Strains Isolated From Ivorian Cocoa Fermentation. J. Food Res. 4: 124-134.

[27] Duthathai, F. and Pathom-Aree, W. (2007). Application of chemical dyes as colour indicator for selective isolation of acetic acid bacteria. Res. J. Microbiol. 2:885-888. 
[28] Lefeber, T., Papalexandratou, Z., Gobert, W., Camu, N. and De Vuyst, L. (2012). On-farm implementation of starter culture for improved cocoa bean fermentation and its influence on the flavor of chocolate produced thereof. Food Microbiol. 30:379-392.

[29] Soares, M. M. C. N., Da Silva, R. and Gomes, E. (1999). Screening of bacterial strain for pectinolytic activity: characterization of the polygalacturonase produced by Bacillus sp. Revista Microbiol. 30:229-303.

[30] Wickerham, L. J. (1951). Taxonomy of yeast. Technical Bulletin No. 1029, United States. Washington DC, Department of Agriculture.

[31] Dicks, L. M. and Van Vuuren, H. J. J. (1987). Microbiology Methods. 6: 273-275.

[32] Kempler, G. M. and Mc Kay, L. L. (1980). Improved medium for detection of citrate fermentating Streptococcus lactis subsp. diacetylactis. J. Appl. Env. Microbiol. 39:927-956.

[33] Aydin, Y. A. and Aksoy, N. D. (2009). Isolation of cellulose producing bacteria from wastes of vinegar fermentation. In: Proceedings of the world congress on engineering and computer science 2009 Vol I, WCECS 2009, October 20-22, 2009, San Francisco, USA.

[34] Lehrian, D. W., Patterson, G. R. (1983). Cocoa fermentation. In: Reed G., Chemie V., Weinheim (Ed), Food and Feed Production with Microorganisms, Biotechnology, vol. 5, pp. 529-575.

[35] Bernfeld, D. (1956). Amylase $\beta$ and $\alpha$, In: method in enzymology 1, Colowick S. P. and Kaplan N. O., Academic Press. pp 149-154.

[36] Gálvez, S. L., Loiseau, G., Paredes, J. L., Barel, M. and Guiraud, J. P. (2007). Study on the microflora and biochemistry of cocoa fermentation in the Dominican Republic. Int. J. Food Microbiol. 114:124-130.

[37] Passos, F. M., Lopez, A. S. and Silva, D. O. (1984). Aeration and its influence on the microbial sequence in cacao fermentations in Bahia, with emphasis on lactic acid bacteria. J. Food Sci. 49: 1470-1474.

[38] Ostovar, K. and Keeney, P. G. (1973). Isolation and characterization of microorganisms involved in the fermentation of Trinidad cacao beans. J. Food Sci. 38:611-617.

[39] Camu, N., Gonzalez, A., De Winter, T., Van Schoor, A., De Bruyne, K., Vandamme, P., Takrama, J. S., Addo, S. K. and De Vuyst, L. (2008). Influence of turning and environmental contamination on the dynamics of lactic acid bacteria and acetic acid bacteria populations involved in spontaneous cocoa bean heap fermentation in Ghana. Appl. Env. Microbiol. 74:86-98.

[40] Nielsen, D. S., Hønholt, S., Tano-Debrah, K. and Jespersen, L. (2005). Yeast populations associated with Ghanaian cocoa fermentations analysed using denaturing gradient gel electrophoresis (DGGE). Yeast. 22:271-284.

[41] Passos, F. M. L., Silva, D. O., Lopez, A., Ferreira, C. L. and Guimaraes, W. V. (1984). Characterization and distribution of lactic acid bacteria from traditional cocoa bean fermentations in Bahia. J Food Sci. 49: 205-208.

[42] Schwan, R. F., Rose, A. H. and Board, R. G. (1995). Microbial fermentation of cocoa beans, with emphasis on enzymatic degradation of the pulp. J. Appl. Bacteriol. Symp. Suppl. 79:96-107S.

[43] Nazina, T. N., Tourova, T. P., Poltaraus, A. B., Novikova, E. V., Grigoryan, A. A., Ivanova, A. E., Lysenko, A. M., Petrunyaka, V. V., Osipov, G. A., Belyaev, S. S. and Ivanov, M. V. (2001). Taxonomic study of aerobic Thermophilic bacilli: Descriptions of Geobacillus subterraneusgen. nov., sp. nov. and Geobacillus uzenensis sp. nov. from petroleum reservoirs and transfer of Bacillus stearothermophilus, Bacillus thermocatenulatus, Bacillus thermoleovorans. Int. J. Sys. Evol. Microbiol. 51:433-446.

[44] Sneath, P. (1986). Endospore-forming Gram-positive rods and cocci. In: Holt J.G. and Sneath P. (Eds), Bergey's Manual of Systematic Bacteriology Vol. 2, Williams and Wilkins, Baltimore, pp.1104-1206.

[45] Leal, G. A.., Gomes, L. H., Efraim, P., Tavares, F. C. A. and Figueira, A. Fermentation of cacao (Theobroma cacao L.) seeds with a hybrid Kluyveromyces marxianus strain improved product quality attributes. FEMS Yeast Res. 2008; 8:788-798.

[46] Afoakwa, E. O., Kongor, J. E., Takrama, J. F., Budu, A. S. (2013). Changes in acidification, sugars and mineral composition of cocoa pulp during fermentation of pulp pre-conditioned cocoa (Theobroma cacao) beans. Int. Food Res. J. 20: 1215-1222.

[47] Kostinek, M., Ban-Koffi, L., Ottah-Atikpo, M., Teniola, D., Schillinger, U., Holzapfel, W. H. and Franz C. M. A. P. (2008). Diversity of predominant Lactic Acid Bacteria associated with cocoa fermentation in Nigeria. Curr Microbiol. 56:306-314.

[48] Penia, M. T., Kresnowati, L. S. and Mirra, A. (2013). Improvement of cocoa beans Fermentation by LAB starter addition. J. Med. Bioeng.; 2:274-278.

[49] Raimbiault, M. (1995). Importance des bactéries lactiques dans les fermentations du manioc. Dans : Agbor Egbe, T., Brauman A., Griffon D. et Trèche S. (Ed ORSTOM), Transformation Alimentaire du Manioc.

[50] Pettiphe, G. L. (1986). Analysis of cocoa pulp and the formulation of a standardized artificial cocoa pulp medium. J. Sci. Food Agr. 37:297-309.

[51] Lefeber, T., Janssens, M., Moens, F., Gobert, W. and De Vuyst, L. (2011). Interesting starter culture strains for controlled cocoa bean fermentation revealed by simulated cocoa pulp fermentations of cocoa-specific lactic acid bacteria. Appl. Env. Microbiol. 77: 6694-6698.

[52] Jespersen, L. (2003). Ocurrence and taxonomic characteristics of strains of Saccharomyces cerevisiae predominant in African indigenous fermented foods and beverages. FEMS Yeast Res. 3:191-200.

[53] Cleenwerck, I. and De Vos, P. (2008). Polyphasic taxonomy of acetic acid bacteria: An overview of the currently applied methodology. Int. J. Food Microbiol. 125:2-14.

[54] Bartowsky, E. J. and Henschke, P. A. (2008). Acetic acid bacteria spoilage of bottled red wine-A review. Int. J. Food Microbiol. 125:60-70.

[55] Lefeber, T., Janssens, M., Camu, N. and De Vuyst, L. (2010). Kinetic analysis of strains of lactic acid bacteria and acetic acid bacteria in cocoa pulp simulation media toward development of a starter culture for cocoa bean fermentation. Appl. Env. Microbiol. 76: 7708-7716. 
[56] Biehl, B. and Voigt, J., Heinrichs, H., Senjuk, V. and Bytof, G. (1993). pH-dependent enzymatic formation of oligopeptides and amino acids, the aroma precursors in raw cocoa beans. In: Lafforest J. (Ed), Proceedings in $\mathrm{XI}^{\text {th }}$ International Cocoa Research Conference. Cocoa Producers' Alliance, Yamassoukro, Ivory Coast, pp.717-722.
[57] Jinap, S. (1994). Organic acids in cocoa beans - A review. ASEAN Food J. 9: 3-12

[58] Matsushita, K., Toyama, H. and Adachi, O. (1994). Respiration chains and bioenergetics of acetic acid bacteria. Adv. Microb. Physiol. 36:247-301. 